\title{
Impact of Climate Change on Aquatic Fauna of Economic Importance in Niger Delta, Nigeria
}

\author{
E. I. Elenwo1, J. A. Akankali² \\ ${ }^{1}$ Department of Geography and Environmental Management, Faculty of Social Science, University of Port \\ Harcourt, Choba, Nigeria \\ ${ }^{2}$ Department of Fisheries, Faculty of Agriculture, University of Port Harcourt, Choba, Nigeria \\ Email: iyke2elenwo@yahoo.com
}

Received 5 August 2014; revised 2 September 2014; accepted 6 October 2014

Copyright (C) 2014 by authors and Scientific Research Publishing Inc.

This work is licensed under the Creative Commons Attribution International License (CC BY).

http://creativecommons.org/licenses/by/4.0/

(c) (i) Open Access

\section{Abstract}

The study discusses the impact of climate change on aquatic lives in the Niger Delta region. To realise this, the study basically adopted a library search design of reviewing literatures of climate change impact on aquatic lives in the Niger Delta region. Meteorological data (rainfall, temperature and humidity) were also extracted from literatures to explain the evidence of climate change in the areas. The meteorological data showed that, temperature, rainfall and humidity have changed over the last 10 years. This change translates to climate change because it is at least up to a decade (10-year period), and it showed a $1.5^{\circ} \mathrm{C}$ rise in temperature from 2003 to 2013 and an increase of $342.2 \mathrm{~mm}$ in the amount of rainfall in Niger Delta. These clearly paint the picture of global warming. Furthermore, in the same period, there was a decrease of $9 \%$ in the amount of humidity in the area. Thus, it is very clear that the climate is changing over time within this region. This certainly has some effects on the aquatic Fauna in the region. In fact, for the next 10 years, the aquatic fauna that now inhabit various habitats may no longer be able to adapt to the changes, leading to their extinction and total elimination from the habitats in question. And as such, these aquatic fauna will either modify their body structure and function in order to tolerate the change in climate, migrate to new and comfortable habitat or even stand the risk of becoming extinct. To abate the impact of climate change in the region, introduction of new water management reform and policy implementation, and carbon sequestration amongst others were recommended. This electronic document is a "live" template. The various components of your paper [title, text, heads, etc.] are already defined on the style sheet, as illustrated by the portions given in this document.

\section{Keywords}

Climate Change, Impact, Aquatic, Fauna, Niger Delta 


\section{Introduction}

Climate change is a significant and lasting change in the statistical distribution of weather patterns over periods ranging from decades to millions of years. The Intergovernmental Panel on Climate Change (IPCC) describes climate change as any change overtime, whether due to natural variability or as a result of intense human activities. It describes past, present or future shift in climate on global, regional or local scales [1]. It may be a change in average weather conditions, or in the distribution of weather around the average conditions (i.e., more or fewer extreme weather events). Climate change is a great threat to fish production, as it is responsible for water scarcity globally, due to increase in greenhouse gases and temperature. Climate change is expected to be the major key player in water scarcity in the nearest future as a result of increase in evaporation from the surface of the sea and this will alter the hydrological processes of water available for fish production. Due to the increase in the level of the pollutants, resulting from water scarcity caused by climate change, which pose a serious threat to the aquatic environment, production of healthy fish on sustainable basis could be hampered. There are some gases that are associated with climate change, which is generally referred to as greenhouse gases. These greenhouse gases are: Carbon dioxide which is released to the atmosphere when solid waste, fossil fuels (oil, natural gas and coal), and wood products are burned; Methane: This is emitted during the production and transport of coal, natural gas, and oil, methane emissions can result from the decomposition of organic wastes in solid waste landfills, and the raising of livestock; Nitrous oxide: This is emitted during agricultural and industrial activities, as well as during combustion of solid waste and fossil fuels.

Greenhouse gases that are not naturally occurring include by-products of foam production, refrigeration, and air conditioning and are called chlorofluorocarbons (CFCs), as well as hydro fluorocarbons (HFCs) and per fluorocarbons (PFCs) generated by industrial processes. HCFs and PFCs are the most heat-absorbent. Methane traps over 21 times more heat than $\mathrm{CO}_{2}$, and $\mathrm{N}_{2} \mathrm{O}$ absorbs 270 times more heat than $\mathrm{CO}_{2}$. Often, estimates of greenhouse gas emissions are presented in units of millions of metric tons of carbon equivalents (MMTCE), which weighs each gas by its GWP value, or Global Warming Potential [2]. Water quality degradation resulting from climate change is a source of water scarcity and this often reduces production capacity in fisheries and aquaculture. Even, the effluent water from aquaculture that promised to be sustainable after recycling is no longer available to poor fish farmers. The hope for sustainable fish production in Nigeria is dashed as a result of poor water quality and scarcity in nearest future. There is therefore the need to sensitize fishermen on the imminent hazards of persistence water scarcity and poor quality as evidence of climate changes that could affect fish production [3]. On the one hand, water which is vital to the survival of ecosystems, plants and animals that lives in them are being threatened; and as such reduces the species of fish caught, and the quantity and quality of water that is available for the inhabitants [4]. Higher temperatures reduce dissolved oxygen levels, which can have an effect on aquatic life. Where stream flow and lake levels fall, there is less dilution of pollutants; and increased frequency and intensity of rainfall will produce more pollution and sedimentation due to runoff [5], which further impinged on the water quality in the region. In the Niger Delta, the incidence of ocean acidification, decreased $\mathrm{pH}$, local extinctions of fish species, eminence of harmful algal bloom, absence of nursery for young fish, reduced primary production as well as migration of fish all clearly show the impact of climate change on aquatic fauna in the region. Based on these problems, the study is set to assess effects of climate change on the aquatic fauna in the Niger Delta region as well as to outline the management options of climate change that will protect the aquatic fauna in the region.

\section{Methods of Study and Study Area}

The study basically adopted a library search design of reviewing literatures of climate change impact on aquatic lives in the Niger Delta region. Climate data were also extracted from literatures to explain the evidence of climate change in the areas. The Niger Delta is ancient and has a history of sedimentation spanning tens of millions of years, with three main depositional cycles: Middle Cretaceous, Palaeocene, and Eocene to the Holocene. In the Pleistocene, during a period of low sea level, the Niger River cut a deep gulf into the ancient delta. The present Niger Delta was formed during the Holocene since the end of the last Ice Age. Over the last 6000 years the delta floodplain has advanced across brackish water mangrove swamps and the delta front beach ridges have been built up progressively further seawards. At the present times, two thirds of the sediment delivered to the delta by the Niger is supplied by the Benue [6].

White Water and Black Water Rivers of the region describes a relatively nutrient-rich silt-laden white-water 
river (e.g., the Niger and Orashi Rivers) and nutrient-poor black water rivers (e.g., the Sombreiro and New Calabar Rivers) converge at the delta. Black water rivers contain a majority (65\%) of forest fish species while, White water rivers are dominated by savannah species (46.5\%) but also contain a number of forest species. Forest species are typically smaller and unlikely to undergo large migrations [6]. Savannah species are more likely to migrate to and utilize floodplains, as well as to survive the more severe dry season of the savannas. The Niger Delta consists of three major sections: The upper riverine floodplain, the lower tidal floodplain, and an outer chain of coastal barrier islands [7].

The upper riverine floodplain stretches for $168 \mathrm{~km}$ from the head of the delta at Onitsha to the lower tidal floodplain. The Niger begins to separate into the Forcados and the Nun Rivers in the upper riverine floodplain, where seasonal and permanent freshwater swamps occur. Seasonal swamp forest, dominated by Anthocleista vogelii, Carapa procera, and Chrysobalanus orbicularis, is inundated during the wet season. Permanent swamp forests, with forest floors that are inundated year-round, include members of the Alstonia, Mitragyna, and Raphia genera [7]. Swamp forests of the upper riverine floodplain grade into mangrove forests on the lower tidal floodplain. In addition to the Nun, Forcados and Orashi Rivers, other main channels of the tidal floodplain are; Sombriero, Bonny, Brass, and New Calabar. Mangrove forest covers approximately $5000 \mathrm{~km}^{2}$ of the delta and species include Rhizophora racemosa (up to $40 \mathrm{~m}$ height), $R$. harrisonii, and $R$. mangle [7] [8]. Sediments from the Niger River, sculpted by marine processes, have created the 20 major islands along the coast of the delta. In total, the islands comprise a surface area of $2000 \mathrm{~km}^{2}$ and several of them reach heights of $4 \mathrm{~m}$ above sea level [7] [9].

\section{Causes of Climate Change}

Climate change is caused by various factors that include the natural and anthropogenic factors as follows: Natural factors are: Ocean circulation: Ocean circulation is the large scale movement of waters in the ocean basins. Seawater flows along the horizontal plane and in the vertical. Typical speeds of the horizontal flow or currents are $0.01-1.0 \mathrm{~m} / \mathrm{s}$; vertical speeds within the stratified ocean are much smaller, closer to $0.001 \mathrm{~m} / \mathrm{s}$. Variations in solar radiation received by Earth; the amount of solar radiation that the earth receives, determines the climate and as the solar radiation changes, the climate changes alongside. The sun, which ultimately regulates all aspects of life on the planet earth, goes through periods of increased and decreased solar activity, which in turn affects how much energy, which in turn affects how much energy the earth receives. These cycles can vary in length from a little as ten years to many millions of years. Plate tectonics; Plate tectonics is a scientific theory that describes the large-scale motions of earth's lithosphere. The lithosphere is broken up into tectonic plates. The plates move horizontally, relative to neighbouring plates, on a layer of softer rock immediately below (ansthe-nosphere). Not all earth quakes occur at plate boundaries. The earth quake that occurs within the plate boundaries are called inter plate earth quakes. In February, 2011 a deep inter plate earth quake occurred in Washington State United States of America. Volcanic eruptions; During a volcanic eruption, lava, tephra (ash, lapilli, volcanic bombs and blocks), and various gases are expelled from a volcanic vent or fissure. Volcanoes that occur along coastal zones, like in Japan and island arcs throughout the world, can cause several effects that might generate a tsunami.

Anthropogenic factors or Human-induced alterations of the natural world; these latter effects are currently causing global warming, and "climate change" is often used to describe human-specific impacts. These processes are known as forcing mechanisms. Forcing mechanisms can be either "internal" or "external". Internal forcing mechanisms are natural processes within the climate system itself (e.g., the thermohaline circulation). External forcing mechanisms can be either natural (e.g., changes in solar output) or anthropogenic (e.g., increased emissions of greenhouse gases through gas flaring in this region, urbanization processes, deforestation, waste incineration etc ). Whether the initial forcing mechanism is internal or external, the response of the climate system might be fast (e.g., a sudden cooling due to airborne volcanic ash reflecting sunlight), slow (e.g. thermal expansion of warming ocean water), or a combination (e.g., sudden loss of albedo in the arctic ocean as sea ice melts, followed by more gradual thermal expansion of the water). [5] opined that the human induced causes of climate change out weighed the natural factors, as such mitigation and adaptation measures are now geared toward managing the human factors.

Despite the factor or a combination of factors causing climate change, the phenomenon often has certain characteristics, which include the following three main characteristics; Rising heat wave, loss of water and continual pollution of water bodies through oil spillages, especially among oil exploration host communities are the 
major characteristics of climate changes which equally has telling effects on animals like fish, seaweeds and other water creatures. These effects are discussed below.

\section{Climate Change Impact}

Impact as used in this context refers to the negative effects of climate change on the aquatic fauna. Scientists have reviewed the likely severity of impacts of Australian marine life, based on the expected responses of 13 groups of species to predicted changes in temperature, salinity, wind, chemistry, circulation and sea level [10]. Due to lack of observations about changes in species, distribution and populations, and a view that responses in Australian waters will be similar to international influences, a mix of information is used to determine likely impacts based on four categories:

1) Effects on distribution and stocks: there is endanger species in the region (see Table 1). The species are generally expected to move southward with warming; species such as Thecosomata (sea butterflies) reliant on building shells are likely to decline in abundance.

2) Effects on the timing of life cycle events: the timing of blooms and migrations are expected to occur earlier with warming.

3) Effects on physiology and behaviour: environmental change will directly affect rates of metabolism, reproduction, development, photosynthesis and respiration.

4) Effects on communities and productivity: this is dependent on the place of the species in relation to ecosystem functioning, for example the place of a species in the food chain.

\subsection{Climate Characteristics of Rivers State}

Tables 2-5 showed the climate characteristics of Rivers State.

The wettest area is the southern fringe with Opobo and Onne having a mean annual rainfall of $3816.8 \mathrm{~mm}$ and $2438.4 \mathrm{~mm}$ respectively. Degeme located in the western axis of the State has the least mean annual rainfall of $2355.1 \mathrm{~mm}$ while Port Harcourt, located at the northern part of the State, has a high rainfall of $2370.5 \mathrm{~mm}$ (see Table 2), because of its elevation and urban factors especially pollution from the industries. Seasonal variations

Table 1. Endangered faunas in the niger delta.

Fauna type and Description Comments on the faunas and associated ecology

Both black and white water rivers flow into the highly productive Niger Delta, which supports an extremely rich freshwater fauna and includes the highest concentration of monotypic fish families in the world. The five

Fish fauna: monotypic fish families are; Denticipidae, Pantodontidae, Phractolaemidae Hepsetidae, and Gymnarchidae. Cichlids, Citharinids, Rivulines In all the 150 freshwater fish within the ecoregion, about twenty are endemic, including several freshwater and Mormyrids dominate the representatives of marine families. The vulnerable, near-endemic freshwater stingray (Dasyatis garouaensis) fish fauna. and the endangered thorny freshwater stingray (Urogymnus ukpam) live in the delta [11] (IUCN 2002). Other noteworthy aquatic biotic elements: Sixty percent of Nigeria's mangrove forests (the third largest in the world and the largest in Africa) are found within the Niger Delta.

Aquatic Mammals:

Aquatic mammals present in the delta include the hippopotamus (Hippopotamus amphibius) and the vulnerable pygmy hippopotamus (Hexaprotodon liberiensis) [12] (Moffat \& Linden 1995). The vulnerable West African manatee (Trichechus senegalensis), semi-aquatic sitatunga (Tragelaphus spekei), marsh mongoose (Atilax Paludinosus), and the spotted-necked otter (Lutra maculicollis) also inhabit the eco-region.

Aquatic Birds:

Other Aquatic Fauna:

Crocodiles:

Endemic Fishes:
The mangrove forests of the tidal floodplain are also important for numerous water birds, including species of heron (Ardeidae), ibis (Threskiornithidae) and pelican (Pelecanidae).

Eleven species of frogs, a variety of monitor lizards, and three turtle species also reside in the delta.

Crocodiles include the slender-snouted (Crocodylus cataphractus), Nile (C. niloticus), and the vulnerable dwarf crocodile (Osteolaemus tetraspis).

Among the monotypic families, the endemic denticle herring (Denticeps clupeoides, family Denticipidae) and the hingemouth (Phractolaemus ansorgii, family Phractolaemidae) have the most limited distributions. The hingemouth possesses a completely alveolated swim bladder that functions as lungs and permits the species to survive in un oxygenated waters. Pantodon buchholzi, also from a monotypic family (Pantodontidae), is capable of aerial respiration with its swim bladder and also can leap out of the water for short distances and glide.

Source: [12]-[14]. 
Table 2. Annual and seasonal variations of rainfall in selected locations in Rivers State.

\begin{tabular}{rcccccc}
\hline S/N & Station & $\begin{array}{c}\text { Mean annual } \\
\text { rainfall }\end{array}$ & $\begin{array}{c}\text { Dry season rainfall } \\
\text { Nov.-Feb. }\end{array}$ & $\begin{array}{c}\text { Wet season rainfall } \\
\text { Mar.-Oct. }\end{array}$ & $\begin{array}{c}\text { \% of mean rainfall } \\
\text { for wet season }\end{array}$ & $\begin{array}{c}\text { \% of the mean } \\
\text { rainfall for dry } \\
\text { season }\end{array}$ \\
\hline 1 & Ahoada & 2370.1 & 187.1 & 2206.4 & 93.10 & 6.90 \\
2 & Port Harcout & 2370.5 & 237.9 & 2138.9 & 90.23 & 9.77 \\
3 & Degeme & 2355.1 & 257.9 & 2097.9 & 89.07 & 10.93 \\
4 & Onne & 2438.4 & 222.4 & 2225.3 & 91.26 & 8.74 \\
5 & Opobo & 3816.8 & 370.4 & 3456.4 & 90.56 & 9.44 \\
\hline
\end{tabular}

(Source: [15]).

Table 3. Mean annual rainfall distribution for port harcourt (2003-2012).

\begin{tabular}{ccccc}
\hline S/N & Year & Value $(\mathrm{x})$ & $(\mathrm{x}-\mathrm{x})$ & $\mathrm{X}$ \\
\hline 1 & 2003 & 2407.8 & 149.5058824 & 2258.294118 \\
2 & 2004 & 1877.5 & -380.7941176 & 2258.294118 \\
3 & 2005 & 2022.9 & -235.3941176 & 2258.294118 \\
4 & 2006 & 2618.8 & 360.5058824 & 2258.294118 \\
5 & 2007 & 2357.6 & 99.30588235 & 2258.294118 \\
6 & 2008 & 2011.2 & -247.0941176 & 2258.294118 \\
7 & 2009 & 2564 & 305.7058824 & 2258.294118 \\
8 & 2010 & 2186.7 & -71.59411765 & 2258.294118 \\
9 & 2011 & 1755.8 & -502.494118 & 2258.294118 \\
10 & 2012 & 2750 & 491.705882 & 2258.294118 \\
\hline
\end{tabular}

Source: [16].

Table 4. Mean annual temperature distribution for port harcourt (2003-2012).

\begin{tabular}{ccccc}
\hline S/N & Year & Value $(\mathrm{x})$ & $(\mathrm{x}-\mathrm{x})$ & $\mathrm{X}$ \\
1 & 2003 & 26.49167 & 0.29582 & 26.19585 \\
2 & 2004 & 26.51667 & 0.32082 & 26.19585 \\
3 & 2005 & 26.61667 & 0.42082 & 26.19585 \\
4 & 2006 & 26.84545 & 0.649608 & 26.19585 \\
5 & 2007 & 26.61667 & 0.42082 & 26.19585 \\
6 & 2008 & 26.375 & 0.179153 & 26.19585 \\
7 & 2009 & 26.6 & 0.404153 & 26.19585 \\
8 & 2010 & 26.77273 & 0.57688 & 26.19585 \\
9 & 2011 & 26.59 & 0.39415 & 26.19585 \\
\hline
\end{tabular}

Source: [16].

of rainfall in the State show that $90 \%$ of the rain is received during the rainy season with the southern part, especially Opobo and Onne, recording the highest amount of rainfall. In Opobo high rainfall is due to closeness to 
Table 5. Mean annual humidity distribution for port harcourt (2003-2012).

\begin{tabular}{ccccc}
\hline S/N & Year & Mean & Departure from Mean & X \\
\hline 1 & 2003 & 85 & 3.4375 & 81.5625 \\
2 & 2004 & 84 & 2.4375 & 81.5625 \\
3 & 2005 & 85 & 3.4375 & 81.5625 \\
4 & 2006 & 85 & 3.4375 & 81.5625 \\
5 & 2007 & 82 & 0.4375 & 81.5625 \\
6 & 2008 & 83 & 1.4375 & 81.5625 \\
7 & 2009 & 83 & 3.4375 & 81.5625 \\
8 & 2010 & 85 & 3.4375 & 81.5625 \\
9 & 2011 & 78.64 & -2.9225 & 81.5625 \\
10 & 2012 & 76 & -5.5625 & 81.5625 \\
\hline
\end{tabular}

Source: [16].

the coast, marine effect, and orographic effect. The above report on the annual and seasonal variations of rainfall in Niger Delta clearly shows a constant change in rainfall patterns which is a prove of climate change in the region.

From 4, the Mean annual temperature is high throughout the state, although little spatial variation occurs. Port Harcourt station has mean annual temperature of $28^{\circ} \mathrm{C}$; Onne which is located further inland records a temperature of $28.2^{\circ} \mathrm{C}$, while Bonny, on the coast records a mean annual temperature of $27^{\circ} \mathrm{C}$. It should be stated that the amount of solar radiation received in Rivers State is substantially reduced due to cloudiness (arising from its coastal location), harmattan and vegetation. The state has a mean daily maximum temperature of $30^{\circ} \mathrm{C}$. Highest mean daily maximum temperature is recorded during the dry season months of February, March and April. For instance mean daily maximum temperature is $35.1^{\circ} \mathrm{C}$ while that of March is $36^{\circ} \mathrm{C}$. The mean monthly minimum temperature for the state is $28^{\circ} \mathrm{C}$, with a peak of $32^{\circ} \mathrm{C}$. Generally, both the minimum and maximum temperature crease from the coast towards the mainland. In terms of diurnal and annual range of temperature, Rivers State has annual range of $3.08^{\circ} \mathrm{C}$; while the diurnal range is higher than the annual range because of differences in diurnal rhythms between day and night. The daily range for Port Harcourt is $7.5^{\circ} \mathrm{C}$ [15]. From this report on the pattern of temperature, it shows that the temperature in Niger Delta is changing with time, pointing to an empirical evidence of climate change.

Table 5 showed the relative humidity in the area, and it revealed that the seasonal variations occur in the distribution of relative humidity in Rivers State due to the seasonal variation in the month of isolation. It should be noted that the apparent movement of the sun through the region creates two periods of low relative humidity separated by a period of high relative humidity. The state has a mean annual figure of 85\% with the rainy season months of June, July, August, September and October recording the highest values. Relative humidity is low during the dry season months of December to February. In terms of diurnal variations, maximum relative humidity occurs in the night between 21:00 and 07:00 GMT; while the lowest relative humidity occurs during the afternoon between 1000 and 1600 GMT. Spatial variation is very low in monthly and annual variations of relative humidity, with higher values in the coastal areas [15]. The present report shows a change in humidity over time in Niger Delta, the continuation of this for a period of at least a decade (which is sure from the present report) will bring about climate change in the region.

From the meteorological data given, in (Tables 2-5) respectively, temperature, rainfall and humidity have changed over the last 10years. This change translates to climate change because it is at least up to a decade (10 year period). This shows that; Between 2003 and 2013, there was an increase of $342.2 \mathrm{~mm}$ in the amount of rainfall in Niger Delta (i.e., 2750 - 2407.8) Also between the period, there was an increase of $1.5^{\circ} \mathrm{C}$ in temperature in the area (i.e., 28 - 26.49167), which clearly paints the picture of global warming. Furthermore, between the same period, there was a decrease of -9 in the amount of humidity in the area (i.e., 76 - 85). From the foregoing, it is very clear that the climate is changing over time within the region. In essence, in at least the next 10 
years, the aquatic fauna that now inhabit various habitats may no longer be able to adapt to the changes, leading to their elimination from the habitats in question. This implies that these aquatic fauna will either modify their body structure and function in order to tolerate the change in climate, migrate to new and comfortable habitat or even stand the risk of becoming extinct.

\subsection{Real and Potential Impact of Climate Change on Important Fauna's of Niger Delta}

Marine ecosystems are vulnerable to the impacts of climate, since they already face a myriad of stresses, including over harvesting and habitat destruction from commercial fisheries, coastal development and pollution [11]. The Niger Delta marine ecosystems is faced with similar problems especially the issue of pollution resulting from oil exploration, which stress the ecosystem. The already stressed ecosystem becomes really vulnerable to the impacts of climate change. The Niger Delta has extensive coast line and adjourning marine ecosystem, with abundance of marine species of faunas both economic, biological and recreational importance; For example, the coastal environment of the Niger Delta supports artisanal fishing activities of over five hundred thousand $(500,000)$ families [17]. Other downstream socioeconomic activities being supported by the artisanal fisheries sector of the Niger Delta marine ecosystem are notably the Clupeids, Prawns, Oysters, Periwinkles, Croaker and Ethmalosa Sp. (Bonga fishery) etc. fish species spp, include processing/preservation, marketing, supplies of fishing inputs, transportation etc. This makes impact of climate change to the marine ecosystem of the Niger Delta region to be justifiably significant. Inland water ecosystems are negatively affected by climate change because; more than $20 \%$ of the world's freshwater fish species have become extinct, threatened and endangered in recent decades [18]. For instance, the vulnerable, near-endemic freshwater stingray (Dasyatis garouaensis) and the endangered thorny freshwater stingray (Urogymnus ukpam) live in the delta [11]. The Niger Delta region is rich in fresh water resources and by extension fresh water fish species. Thus similar impacts that climate change have on such species in other parts of the globe can be implicated for the Niger Delta region. Some other specific impacts of climate change on aquatic resources within the Niger Delta region include the following:

Absence of Nursery for Young Fish: Estuaries, mangroves, coral reefs and sea grass beds are particularly significant in the provision of ecosystem services, especially as nurseries for young fish [19]. This peculiar ecology is amongst the most sensitive and highly exposed to the negative impacts of climate change. The Niger Delta for instance is not new to oil exploration, which releases carbon that often brings about climate change (when the carbons combine with other atmospheric gases). Consequently, estuaries, mangroves and other nursery beds are destroyed and this results in absence of nursery for young fish, due to increase in ambient temperature of traditional breeding grounds of certain species. As a result, there has been a series of reported decline in fish catches within the region, especially from the artisanal fishing sub sector [20]. Generally, as a result of climate change, young fish no longer have nursery grounds. Some fishes have migrated and local extinction has even occurred in some cases as a result of climate change. Climate change has resulted in reduced primary productivity as well as harmful algal bloom becoming eminent. Ocean acidification has been increased while $\mathrm{pH}$ has been decreased as a result of climate change.

Migration of Fish: All marine and aquatic invertebrates (molluscs, crustaceans, worms etc.) and fish are poikilotherms; their internal temperature varies directly with that of their environment. This makes them very sensitive to changes in the temperature of their surrounding environment. When changes do occur they move to areas where the external temperature allows them to regain their preferred internal temperature. Fish also tend to live near their tolerance limits of a range of factors; as a result, increased temperature and acidity, lower dissolved oxygen and changes to salinity can have deleterious effects [21]. This "behavioural thermoregulation", according to [21] is resulting in rapid migrations pole ward or into cooler bodies of water corresponding to the pole ward shift of climatic zones. As a result, benefits are likely to accrue at higher latitudes and losses will be experienced in the tropics. Some species will also shift from shallow coastal waters and semi-enclosed areas, where temperatures will increase fastest, into deeper cooler waters. This will in turn bring about a reduction in maximum catch potential. In addition, increased industrial activities in the Niger Delta over the years have made the issue of climate change a common place in the region. As a result, the temperature is increasing at such a rate that makes aquatic fauna to migrate from the Niger Delta region. In this way important aquatic fauna are lost and those that manage to survive the harsh condition don't do well as a result of increased metabolic rate.

Local Extinctions of Fish Species: Where fish continue to inhabit warming bodies of water, the increases in temperature will increase their metabolic rate slowing growth and reducing maximum size [21]. There are likely 
to be local extinctions of fish species at the edges of their ranges, especially among freshwater and diadromous species [5]. However, overall extinction rates for marine species are lower than those predicted for terrestrial species $(15 \%-37 \%)$, in part due to their higher potential for migration [22]. As mentioned above, a $1^{\circ} \mathrm{C}-3^{\circ} \mathrm{C}$ temperature rise relative to 1990-2000 would result in the bleaching and possible death of most of the world's coral reefs [5]. This would have serious negative effects on coastal reef fisheries. The Niger Delta is faced with the issue of continues warming of water bodies resulting from several industrial activities. After the ice age about 200,000 years ago, the global air temperature has risen 3 degrees, leading to an increase in sea temperatures [23]. Migration is often the strategy employed by aquatic fauna to combat this effect. Migration of fishes may continue to such a time where some fish species becomes extinct in the region, although they may be found in other parts of the country with favourable temperature. [24], reported an extinction of various endemic species within the Niger Delta region and climate change cannot be completely be absolved of implication of one of the causative factors in this regard.

Reduced Primary Production: Changes in the temperature ranges will also change the location of areas with high primary productivity. These areas are important to marine mammals because primary producers are the food source of marine mammal prey or are the marine mammal prey themselves. Marine mammal distribution and abundance will be determined by the distribution and abundance of its prey. Migration of marine mammals may also be affected by the changes in primary productivity [25]. Primary productivity is affected by availability of nutrients in the water, which in turn depends on freshwater run-off and ocean mixing as well as levels of light and temperature. In some areas reduced precipitation could lead to reduced run-off from land, starving wetlands and mangroves of nutrients and damaging local fisheries. The Niger Delta which is often hit by constant fluctuation in temperature ranges due to industrial activities is faced with the challenge of change in location of areas with primary productivity, since the entire food web is suspected to be highly altered adversely.

Dominance and Harmful Algal Bloom: In other areas increased precipitation or increased extreme weather events, including flooding, will lead to excessive nutrient levels in rivers, lakes and coastal waters as sewage and fertilizer is washed into water bodies causing harmful algal blooms, also known as red tides [21] [26]. For example, the 2012 flood which occurred in the Niger Delta would have washed enormous quantities of sewage and fertilizer into the water bodies in the region, leading to the emergence of harmful algal bloom. The change has the potential to affect the occurrence and severity of HABs because the growth, toxicity, and geographic distributions of HAB species (like all phytoplankton) are impacted by environmental variability. Additionally, the susceptibility of shellfish, fish, and marine animals to the impacts of HABs can be exacerbated by other stressors that are also caused by climate changes. Recent data shows that unusual or unprecedented algal blooms have been linked to climate anomalies [27]-[30]. Similarly, climate changes in the Niger Delta have further worsened the effect of harmful algal bloom. Evidence also indicates that climate warming may benefit some species of harmful cyanobacteria (both freshwater and marine) by providing more optimal conditions for their growth [30]. In view of this, the Niger Delta with increased climate warming may provide more optimal condition for the growth of harmful cyanobacteria to the detriment of important aquatic fauna. Increasing temperature and $\mathrm{CO}_{2}$ either alone or in combination with nutrient availability may determine the growth and relative abundance of HAB species [31]; thus the Niger Delta with a steady increase of carbon resulting from industrial activities is usually faced with the growth and abundance of harmful algal bloom species. Historical evidence from long term phytoplankton monitoring data and fossil records suggests that future climate warming could impact HABs through the alteration of their geographic range and shifts toward relatively more and earlier blooms [32]. For instance, the Niger Delta region will experience increased abundance of harmful algal blooms as a result of the steady increase in climate warming of the region.

Decreased pH and Increased Ocean Acidification: Niger Delta aquatic ecosystems, absorb a large amount of carbon dioxide from the atmosphere, and cause an increase in carbon dioxide concentration and decrease its overall $\mathrm{pH}$, increasing ocean acidification. This increase in the acidification of the ocean makes the water body toxic to the aquatic fauna. This is due to the fact that aquatic fauna does not need a basic nor acidic $\mathrm{pH}$. The $\mathrm{pH}$ of the water should neither be basic nor acid, but it should be balanced, depending on the aquatic fauna; since aquatic fauna have different optimum $\mathrm{pH}$ requirement. The rising ocean acidity makes it more difficult for marine organisms such as shrimps, oysters, or corals to form their shells-a process known as calcification. Many important animals, such as zooplankton, that forms the base of the marine food chain have calcium shells. Thus the entire marine food web is being altered-there are "cracks in the food chain". As a result, the distribution, productivity, and species composition of global fish production is changing, generating complex and in- 
ter-related impacts on oceans, estuaries, coral reefs, mangroves and sea grass beds that provide habitats and nursery areas for fish. Changing rainfall patterns and water scarcity is impacting on river and lake fisheries and aquaculture production. For instance, the release of carbon from industrial activities to the atmosphere in Niger Delta contributes in no small measure to the acidity of the ocean bringing about difficulty in calcification. This in turn lowers the primary productivity of shell-bearing aquatic fauna in the region [14]. With increased acidification which is a direct consequence of climate change, the water body gradually becomes intolerable for the aquatic fauna. This will affect the growth rate, maximum size and survival of fish. To the extreme, death of aquatic fauns is imminent.

\section{Management Options}

In order to counter the adverse impacts of climate change in the Niger Delta region, the following are recommended. These recommendations is feasible because they are the fallout of Kyoto and Copenhagen conventions, and most parties involved have since key into its implementation.

\subsection{Introduction of New Water Management Reform and Policy Implementation}

The freshwater and marine ecosystem in the Niger Delta should be protected from the adverse effect of climate change by introducing new water management reform laws. This can be achieved by monitoring the activity of industries that emit carbon into the atmosphere. In this way, carbon from industries will be properly channelled and released.

\subsection{Government Investment in Advance Technology}

Government investment in advanced technology and infrastructure with the integrated efforts in water management and agricultural research policy on the use of water in agriculture sectors [3], will also help to reduce the impact of climate change on aquatic fauna in the region. The government can reduce the amount of $\mathrm{CO}_{2}$ from industries into water bodies by investing in advanced technology and infrastructure. With these technologies in place, the climatic condition of the water ecosystem can relatively be stable; thereby reducing the problems associated with climate change.

\subsection{Carbon Sequestration}

This is the long-term storage of carbon in the biosphere (trees) or subsurface terrestrial (soil) features, in order to reduce its concentration in the atmosphere. Since carbon is one of the gases usually associated with climate change, the constant and long-term storage of carbon in the biosphere will go a long way to reduce carbon presence in the atmosphere. In the Niger Delta, the government should invest in the following; Improved Forest management (IFM), affore station and reforestation, organic agriculture and agro forestry practice [33]. By this means, carbon which is a major problem associated with climate change will be sequestered (stored) in the biosphere, as being practiced in other countries of the world.

\subsection{0\% Reduction of Greenhouse Gas Emission by 2017/Total Stoppage of Gas Flaring}

It is targeted by policy of the Nigerian government to reduce by $50 \%$ greenhouse gas emission as recommended [34]. By direct implication, such a level of reduction in greenhouse gas emission (which causes climate change) in the region will reduce impact on the aquatic fauna by approximately same level of $50 \%$ by 2017 . The total stoppage of gas flaring is more feasible on reducing climatic vagary in the region.

\subsection{Switching to Low-Carbon Energy Sources.}

Finally, industries in the Niger Delta region whose energy source emit carbon should reduce their level of carbon emission, by resorting to low-carbon energy sources, such as renewable (solar) and nuclear energy. When this is done, it will lower the temperature of the region

\section{Conclusion}

It is no longer news that climate change in the Niger Delta has led to absence of nursery for young fish, migra- 
tion of fish, local extinctions of fish species, reduced primary production, dorminance of harmful algal bloom as well as decreased $\mathrm{pH}$ and increased ocean acidification. Nevertheless, all these problems associated with climate change in the region can be overcome by: introduction of new water management reform and policy implementation, government investment in advance technology, carbon sequestration, reduction of greenhouse gas emission and switching to low-carbon energy sources. In view of this, the challenge of climate change in the Niger Delta, just like other challenges is surmountable.

\section{References}

[1] Henson, R. (2006) The Rough Guide to Climate Change. Rough Guides Ltd., London.

[2] Sridhar, D. (2010) The House We Live in: An Environment Reader. University of Michigan, Ann Arbor.

[3] Adesina, B.T. and Omitoyin, B.O. (201 1) Potential of Moringa oleifera (Lam.) Fresh Root-Bark Extract as an Organic Piscicide in Aquaculture Pond Management. Egyptian Journal of Biology, 13, 8-13.

[4] Rosegrant, D.R. (2002) Consideration in Conducting Bio Assay Technology Report. Army Water Engineers, Waterways, Vicksburg.

[5] IPCC (2007) Climate Change; Impacts, Adaptions, and Vulnerability. In: Parry, M.L., Canzaiani, O.F., et al., Eds., Contribution of Working Group 11 to the Fourth Assessment Report of the Intergovernmental Panel on Climate Change, Cambridge University Press, Cambridge, 1000p.

[6] Lowe-Mcconnenel, R.H. (1987) Ecological Studies in Tropical Fish Communities. Cambridge University Press, Cambridge, UK.

[7] Hughes, L. (2003) Climate Change and Australia: Trends, Projections and Impacts. Austral Ecology, 28, 423-443.

[8] Shunway, L. (1999) A Pilot Survey of Global Disaster of Past Twenty Years. Natural Hazards. Research University of Toronto, Toronto.

[9] Ajao, E.O. (1994) Coastal Aquatic Ecosystem, Conservation and Management Strategies in Nigeria. Southern African Journal of Aquatic Sciences, 20, 3-22.

[10] Alistair, H., Tom, O. and Craig, M. (2011) Impacts of Climate Change on Australian Marine Life: A Report Prepared by Spot and Territories as Consultancy for Environmental Protection Agency, Environmental Standards Branch, Parkes.

[11] International Union for the Conservation of Nature: IUCN (2002) Red List of Categories of Species Prepared by IUCN.

[12] Muffet, C. and Laden, A. (1995) Working with Anaerobic Bacteria in Manual of Industrial Microbiology Washington DC.

[13] Food and Agriculture Organisation (FOA) (2008) United Nations Environment Programme Bulletin on Coastal Zone Management and Control, No. 29.

[14] Beadle, L.C. (1981) The Inland Waters of Tropical African: An Introduction to Tropical Limnology. 2nd Edition, Longman, Harlow.

[15] Alagoa, E.J. and Derefaka, A.B. (2010) The Land and People of Rivers State: Eastern Niger Delta. Onyoma Publications, Port Harcourt.

[16] Gobo, A.E. and Akpan, U.F. (2011) Climate Change Vulnerability/Impact Assessment in Rivers State, Safe-Earth Consults Limited.

[17] Ajana, P.O. Acute Toxicity Test of a Textile Mill Waste Water Effluent and a Detergent Wash. Biologia Africana 2 (1).

[18] Bruner, A.G., Gullison, R.E., Rice, R.E. and da Fonseca, G.A.B. (2001) Effectiveness of Parks in Protecting Tropical Biodiversity. Science, 291, 125-128. http://dx.doi.org/10.1126/science.291.5501.125

[19] UNEP 2006 Annual Report ISBN No. 978-92-807-2801-9.

[20] Akankali, J.A. and Jamabo, N.A. (2011) A Review of Some Factors Militating Against Sustainable Artisanal Fisheries Development in Niger Delta, Nigeria. Asian Journal of Agricultural Sciences, 3, 369-377.

[21] Reissig, M., Trochine, C., Queimalinos, C., Balseiro, E. and Modenutti, B. (2006) Impact of Fish Introduction on Planktonic Food Webs in Lakes of the Patagonian Plateau. Biological Conservation, 132, 437-447.

[22] Cheung, W.W.L., Close, C., Kearney, K., Lam, V., Sarmiento, J., Watson, R. and Pauly, D. (2009) Projections of Global Marine Biodiversity Impacts under Climate Change Scenarios. Fish and Fisheries, 10, 235-251.

[23] Nye, J. (2010) Climate Change and Its Effects on Ecosystems. Habitat and Biota. The Gulf of Maine Council on the Marine Environment, Maine, 1-17. 
[24] IPS (2007) Baseline Ecology Studies of Bonny South Field (SPDC) Location. Institute of Pollution Studies (IPS) (RSUST), Port Harcourt.

[25] Wikipedia (2009) Port Harcourt Nigeria. Port Harcourt. http://en.wikipadia.org/wiki

[26] Epstein, P.R. (2000) Is Global Warming Harmful to Health. Scientific American Journal, 5, 20.

[27] Belgrano, A., Lindahl, O. and Hernroth, B. (1999) North Atlantic Oscillation, Primary Productivity, and Toxic Phytoplankton in the Gullmar Fjord, Sweden (1985-1996). Proceedings of the Royal Society of London, Series B: Biological Sciences, 266, 425-430. http://dx.doi.org/10.1098/rspb.1999.0655

[28] Syjodal and Dundas (1991) Environmental Assessment and Human Health. A Background Report for the International Study of the Effectiveness of Impacts.

[29] Cloern, J.E., Schraga, T.S., Lopez, C.B., Knowles, N., Labiosa, R.G. and Dugdale, R. (2005) Climate Anomalies Generate an Exceptional Dinoflagellate Bloom in San Francisco Bay. Geophysical Research Letters, 32, Published Online. http://dx.doi.org/10.1029/2005GL023321

[30] Pearl, H. and Huisman, J. (2008) Blooms Like It Hot. Science, 320, 57-58. http://dx.doi.org/10.1126/science.1155398

[31] Fu, F.X., Zhang, Y., Warner, M.E., Feng, Y., Sun, J. and Hutchins, D.A. (2008) A Comparison of Future Increased $\mathrm{CO}_{2}$ and Temperature Effects on Sympatric Heterosigma akashiwo Prorocentrum minimum. Harmful Algae, 7, 76-90. http://dx.doi.org/10.1016/j.hal.2007.05.006

[32] Dale, B., Edwards, M. and Reid, P.C. (2006) Climate Change and Harmful Algal Bloom. Ecological Studies, 189, 367378. http://dx.doi.org/10.1007/978-3-540-32210-8_28

[33] Oladele, A.I. (2013) Carbon Trading, Advance in Agriculture (AGR.502.1).

[34] Patrick, B. (2013) Climate Change and Politics of Justice, a Proposed Biological Measure of Stream Conditions Based on a Survey of Conestoga Basin, Lancaster Country Philadelphia. 
Scientific Research Publishing (SCIRP) is one of the largest Open Access journal publishers. It is currently publishing more than 200 open access, online, peer-reviewed journals covering a wide range of academic disciplines. SCIRP serves the worldwide academic communities and contributes to the progress and application of science with its publication.

Other selected journals from SCIRP are listed as below. Submit your manuscript to us via either submit@scirp.org or Online Submission Portal.
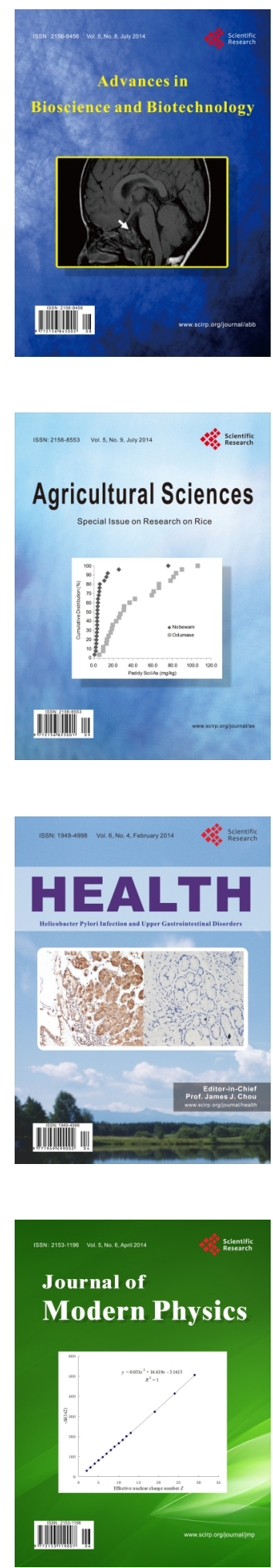
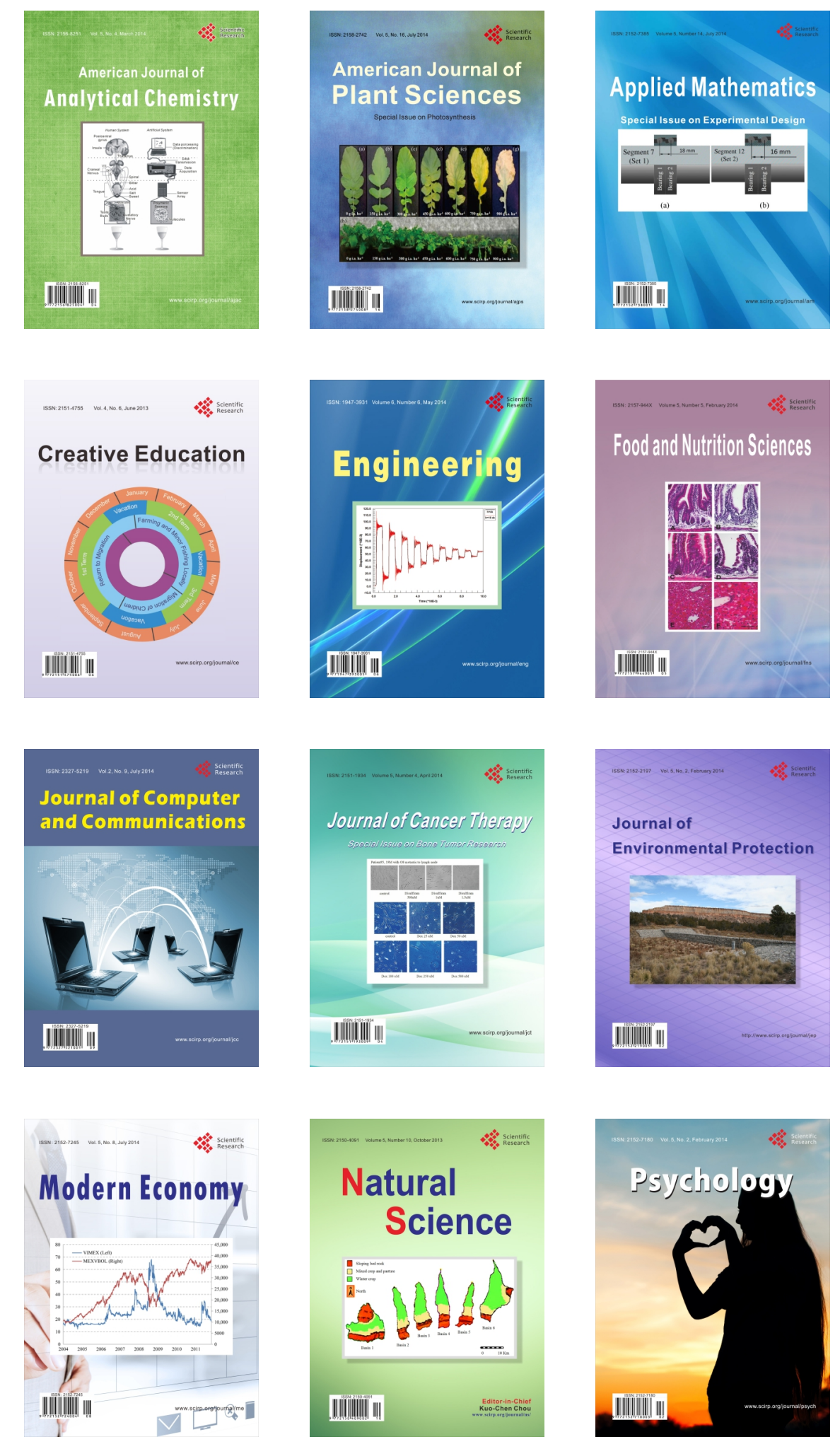